\title{
Predicting the Effects of Cerulean Warbler, Dendroica cerulea Management on Eastern Ontario Bird Species
}

\author{
Jason Jones ${ }^{1}$, William J. McLeish, and Raleigh J. Robertson \\ Department of Biology, Queen's University, Kingston, Ontario K7L 3N6 Canada \\ ${ }^{1}$ Present address, Department of Biology, Vassar College, Poughkeepsie, New York 12604 USA; e-mail: jajones@ \\ vassar.edu
}

Jones, Jason, William J. McLeish, and Raleigh J. Robertson. 2004. Predicting the effects of Cerulean Warbler, Dendroica cerulea, management on eastern Ontario bird species. Canadian Field-Naturalist 118(2): 229-234.

Single-species habitat management strategies are often undertaken without explicit consideration of their effects on the larger community. Here we explore the potential effects of managing eastern Ontario deciduous forests for the Cerulean Warbler (Dendroica cerulea) by examining its potential as a biodiversity indicator species and as an umbrella species. Our results indicate that the Cerulean Warbler would not be an effective biodiversity indicator, as its distribution across the studied landscape did not coincide with areas of high avian species richness. However, the Cerulean Warbler may be effective as an umbrella species for the maintenance of populations of other canopy-nesting species that require mature deciduous forest habitats. It is hoped that the conclusions reached in Ontario, while perhaps not directly transferable to all parts of the breeding range, encourage other Cerulean Warbler researchers to ask similar questions in their study areas.

Key Words: Cerulean Warbler, Dendroica cerulea, conservation utility, biodiversity indicator species, umbrella species, eastern Ontario.

Few North American songbirds are receiving the scientific and conservation attention that is currently focused on the Cerulean Warbler (Dendroica cerulea; Robbins et al. 1992; Rosenberg et al. 2002*; Hamel et al. 2004). The Cerulean Warbler has suffered significant long-term breeding population declines (annual declines of 3.04\% over 1966-2000; Link and Sauer 2002) which are largely attributed to habitat destruction on both the breeding and wintering grounds (Robbins et al. 1992). Concern over the long-term health of this species has led to its designation as threatened, rare, or of special concern in the United States and as a Species of Special Concern in Canada (Robbins et al. 1992; Hamel 2000; COSEWIC 2003*).

In two separate meeting in 2001 and 2002, a group of academic and governmental scientists, land managers, industry biologists and non-governmental organizations formed the Cerulean Warbler Technical Group (CWTG): an effort to develop a proactive, broad-based, multiple stakeholder approach to Cerulean Warbler conservation in both North and Latin America (Hamel et al. 2004). One of the outcomes of these meetings was a breeding grounds research plan that is designed to identify key population limitation factors and explore forest management options for the maintenance and creation of Cerulean Warbler habitat on a rangewide basis.

Ironically, the very thing that limits our ability to currently diagnose specific reasons for breeding ground population declines - a general lack of natural and lifehistory information - may also limit the efficacy of the CWTG research plan. Here, we take advantage of data collected during one of the longest running Cerulean Warbler research programs in North America (dating to 1994; Oliarnyk and Robertson 1996; Jones et al. 2000, 2001, 2004; Jones and Robertson 2001; Barg et al. 2005) to make predictions regarding the potential effects of managing deciduous forests for Cerulean Warblers on sympatric bird species in eastern Ontario. Specifically, we ask two questions. One, will the promotion of Cerulean Warblers and Cerulean Warbler habitat promote the preservation of avian diversity? In other words, is the Cerulean Warbler a biodiversity indicator (sensu Landres et al. 1988)? Two, can the Cerulean Warbler act as an umbrella species for other bird species with similar life - and natural histories? The protection of the habitat of the umbrella species ideally results in the protection of the habitat of those species whose requirements are subsumed by those of the umbrella (Launer and Murphy 1994; Berger 1997; Simberloff 1998).

\section{Study Area and Methods}

This investigation was conducted at the Queen's University Biological Station (QUBS), Ontario $\left(44^{\circ} 34^{\prime} \mathrm{N}, 76^{\circ} 20^{\prime} \mathrm{W}\right)$, within the Great Lakes-St. Lawrence mixed forest region. Our study area was restricted to approximately 2600 ha of research tracts managed by QUBS. The landscape in the area is dominated by mature, secondary-growth, lowland mixed deciduous forest, interspersed with rocky outcrops, marshes, lakes and abandoned agricultural fields. 
Bird surveys. In 1997 and 1998, we surveyed birds on QUBS property using variable-circular-plot point counts (Reynolds et al. 1980; Jones et al. 2000). We surveyed 80 stations in 1997 (17 May - 20 June) and 67 stations in 1998 (21 May - 21 June); the 1998 stations were a subset of those sampled in 1997. The point-count stations were located to maximize spatial coverage of the study area. Each point count was 10 min long. Each station was separated by at least $200 \mathrm{~m}$ to minimize the potential for double-counting individuals. Point counts were conducted between $0.5 \mathrm{hr}$ before sunrise and $3 \mathrm{hr}$ after sunrise EST in order to sample during peak song activity, and were only conducted under calm weather conditions. For our analyses we included birds detected within $100 \mathrm{~m}$ of the plot center. Probability of detection was similar for all species analysed, as the detection thresholds for all but one species (Black-and-white Warbler, Mniotilta varia, $92 \mathrm{~m}$ ) were beyond $100 \mathrm{~m}$ (Jones unpublished data). Data from the first two visits per station each year were used in the analyses to facilitate comparison between years and because two visits are sufficient to confirm the presence or absence of Cerulean Warblers (Jones et al. 2000).

Vegetation Surveys. We collected vegetation data at 59 point-count stations in 1997 at five circular subplots, each with a radius of $5 \mathrm{~m}$. The first subplot was centered on the point count station center and the other four were located $50 \mathrm{~m}$ away in each of the cardinal directions. Within each of the subplots we counted the number of saplings [stems $<3.0 \mathrm{~cm}$ diameter at breast height (dbh)], measured the dbh of all stems $\geq 3.0 \mathrm{~cm}$ and grouped them into two size classes $(3.0-15.0 \mathrm{~cm}$ $\mathrm{dbh}, 15.0-30.0 \mathrm{~cm}$ dbh). Using an imaginary $1 \mathrm{~m}$ radius cylinder projected upward from the forest floor, we estimated cover within $3 \mathrm{~m}$ height intervals from the ground to the top of the canopy. Total cover and percent cover of each woody plant species was estimated by eye in each height interval on a scale of 0 to 10 $(0=0 \%$ cover, $10=100 \%$ cover $)$. Two observers made all cover estimates; the two observers spent several days prior to data collection assuring that their cover estimates were within $10 \%$ of one another. For analysis we reduced these cover estimates to two variables: maximum cover below $6 \mathrm{~m}$ (understory cover) and maximum cover above $12 \mathrm{~m}$ (canopy cover). Each vegetation variable was averaged across subplots to describe the habitat of the point-count station. We measured only those vegetation variables thought to be important to Cerulean Warblers; the importance of these variables has been supported by subsequent research (Jones and Robertson 2001; Jones et al. 2001). We also restricted the number of vegetation variables for analytical reasons (see below).

Data Analysis. In our analyses, we included only those species known to breed in our study area. We also excluded species that are not adequately sampled by diurnal point counts, such as colonial nesters (e.g.,
Barn Swallow, Hirundo rustica), nocturnal species (e.g., Whip-poor-will, Caprimulgus vociferus), waterfowl (e.g., Wood Duck, Aix sponsa), and waders (e.g., Great Blue Heron, Ardea herodias).

\section{(1) Biodiversity indicator evaluation}

We tested whether the presence of Cerulean Warblers was a predictor of overall bird species richness. For the purposes of these analyses, we defined species richness as the number of species detected in the first two visits to a point-count station, excluding the Cerulean Warbler if present. We used randomization tests to compare the mean species richness at stations where Cerulean Warblers were present to the expected species richness at a randomly generated sample of points (Chase et al. 2000). In these tests, the mean species richness was calculated for a random sample of point-count stations, with the number of random stations equaling the number of stations where Cerulean Warblers were detected in a given year. We iterated this procedure 1000 times to generate an expected distribution of mean species-richness values. We then compared the observed species richness associated with Cerulean Warblers and determined its statistical significance. These randomization tests were performed using S-PLUS 4.0 (Mathsoft 1997*). Values reported in the results are means $\pm \mathrm{SE}$.

(2) Umbrella species evaluation

The initial step in evaluating the potential of the Cerulean Warbler as an umbrella species was to establish an ecological context. We categorized the bird species detected during our surveys into species groups based on habitat preferences, diet and foraging substrate, and nesting substrate. These classifications were based on observations reported in the literature (Ehrlich et al. 1988; Robbins et al. 1989a; Freemark and Collins 1992; Canterbury et al. 2000); we did not include our survey data in these classifications. In addition, we created a conservation concern grouping that included species which were experiencing statistically significant population declines as indexed by North American Breeding Bird Survey data for 1966-2000 (Sauer et al. 2001*). For the purposes of these analyses we focused on the groups to which Cerulean Warblers belonged: mature forest habitat ( $\mathrm{n}=13$ species), insectfoliage foragers $(n=15)$, canopy nesters $(n=12)$, and species of concern $(n=14)$.

We used two methods to test if the distribution of Cerulean Warblers was representative of the distributions of other species in the same functional group. First, we used the checkerboard score ( $C$-score) developed by Stone and Roberts (1990) to test for nonrandomness in presence-absence matrices. One of the reasons we selected this metric of co-occurrence is that is not particularly prone to Type 1 error (Gotelli and Entsminger 2000*) and, unlike other co-occurrence metrics, it allows for overlap in species distributions (Gotelli and McCabe 2002; Feeley 2003). We calculated $C$-scores (hereafter, observed $C$-score) for each 
TABLE 1. Interpretation of the principal components axes from analysis of 5 vegetation variables for 59 point-count stations. Bold-face eigenvalues significant following bootstrap analyses.

\begin{tabular}{lrccccll}
\hline \hline Axis & $\mathrm{CV}^{\mathrm{a}}$ & $\mathrm{CC}^{\mathrm{b}}$ & $\mathrm{UC}^{\mathrm{c}}$ & $\mathrm{SPD}^{\mathrm{d}}$ & $\mathrm{SSD}^{\mathrm{e}}$ & LSD $^{\mathrm{f}}$ & Interpretation of positive axis values \\
\hline PC1 & 29.2 & $\mathbf{0 . 6 2 4 9}$ & $\mathbf{- 0 . 6 2 8 1}$ & -0.2509 & 0.0187 & 0.3195 & mature forest with dense canopy \\
PC2 & 54.1 & 0.2676 & 0.2143 & $\mathbf{0 . 7 0 2 4}$ & 0.5205 & 0.3438 & mid-succession forest \\
PC3 & 74.2 & 0.0036 & 0.3208 & 0.1185 & $\mathbf{- 0 . 7 0 4 6}$ & $\mathbf{0 . 6 2 1 8}$ & mid- to late-succession forest \\
PC4 & 88.5 & $\mathbf{- 0 . 4 7 3 7}$ & 0.0870 & -0.4715 & 0.4648 & $\mathbf{0 . 5 7 4 2}$ & mature forest with patchy canopy \\
PC5 & 100.0 & 0.5599 & $\mathbf{0 . 6 7 0 2}$ & -0.4553 & 0.1280 & -0.1171 & early succession forest \\
\hline \hline
\end{tabular}

${ }^{\mathrm{a} C}$ Cumulative variance explained; ${ }^{\mathrm{b}}$ Canopy cover $(\%$ cover $>12.0 \mathrm{~m}) ;{ }^{\mathrm{c}}$ Understory cover $(\%$ cover $<6.0 \mathrm{~m}) ;{ }^{\mathrm{d}}$ Sapling density

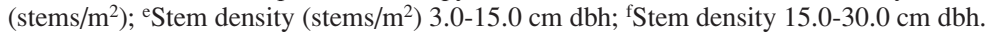

functional group to examine if species within each functional group were distributed randomly across the landscape with respect to one another. For each survey year, we used re-sampling techniques to calculate $10000 C$-scores based on the original presence-absence matrix. The observed $C$-score was then compared with the generated distribution of expected $C$-scores. A $C$ score significantly greater than expected indicates that the assemblage is competitively structured; that is, individual species have distinct, and often exclusive, distributions (Stone and Roberts 1990). Conversely, a $C$-score significantly smaller that expected indicates that there is a degree of cohesion in the distribution patterns of the species included in the matrix. All $C$ score calculations were carried out using EcoSim 5.0 (Gotelli and Entsminger 2000). For all iterations, the number of species detected at each point-count station was kept consistent with the original matrix and each station was equally likely to be inhabited by a given species. Survey results from 1997 and 1998 were analyzed separately.

In our second test, we used logistic regression analyses to predict the probability of occurrence along a habitat gradient for all species within each species group to which Cerulean Warblers belonged. The Red-eyed Vireo (Vireo olivaceus) was not included in these analyses due to its near-ubiquitous distribution. For these analyses we included only the 1997 surveys of the 59 point-count stations for which we collected vegetation data. We generated the habitat gradient by entering all five vegetation variables into a principal components analysis, giving us an approximate 10:1 ratio of sites to variables. We tested the significance of the eigenvalues for each variable within each component using a bootstrap approach, following the recommendations of Peres-Neto et al. (2003). We drew 1000 bootstrap samples by resampling entire rows with replacement, thereby ensuring that the bootstrap matrices had the same dimensions as the original vegetation matrix; we conducted a PCA on each of these 1000 matrices. $P$-values were estimated by the number of bootstrap loadings equal to or less than zero for original loadings that were positive (greater than or equal to zero for negative loadings), divided by 1000 .
For the purposes of this paper, we considered $P=0.10$ as our significance cut-off. The first PC axis (PC1) explained $29 \%$ of the variance of the vegetation data (Table 1); positive values along PC1 represented sites of mature deciduous forest and negative values represented early successional forest. We included PC1 as the independent variable in our logistic regression analyses. All these analyses were performed with JMP IN 4.0.2 (SAS Institute Inc. 2000*) and MS-EXCEL using the PopTools add-in module (Hood 2002). We calculated $95 \%$ confidence intervals around the logistic regression coefficient to facilitate comparison of occurrence probabilities across species.

\section{Results}

(1) Biodiversity indicator - The presence of Cerulean Warblers was not a significant predictor of avian species richness in either 1997 or 1998. In other words, observed species richness at Cerulean Warbler pointcount stations was not significantly different from species richness expected by chance, based on bootstrap analyses (1997, observed richness $12.69 \pm 0.75$ species, expected $13.95 \pm 0.03, P=0.12 ; 1998$, observed $9.75 \pm 0.63$, expected $9.82 \pm 0.03, P=0.83$ ).

(2) Umbrella species - All three of the species groups to which Cerulean Warblers belong exhibited cohesive distributions in both 1997 and 1998, as indexed by their $C$-scores (Table 2). $C$-scores that are significantly lower then expected are indicative of cooccurrence in the distribution patterns of the species included in the analyses. Species of conservation concern also exhibited cohesive distributions in both 1997 and 1998 (Table 2).

The results of the logistic regression analyses using PC1 indicate that species within each of the species groups to which Cerulean Warblers belonged were distributed differentially along the generated habitat gradient, some more so than others (Table 3). Within the mature forest group, only one of the 12 group species (Black-and-white Warbler) did not overlap with the Cerulean Warbler confidence intervals. Similarly, only one of the 12 canopy nesting species (Blue Jay, Cyanocitta cristata) did not overlap with the Cerulean Warbler confidence intervals. Conversely, the insect- 
TABLE 2. Tests for cohesive distributions of functional groups, as indexed by the $C$-score of Stone and Roberts (1990). Estimated values are mean $\pm \mathrm{SE}$ for a generated random distribution based on the actual presence-absence matrix for each group for each year. $C$-scores that are significantly lower then expected are indicative of co-occurrence in the distribution patterns of the species included in the analyses.

\begin{tabular}{|c|c|c|c|c|c|c|}
\hline \multirow[b]{2}{*}{ Functional Group } & \multicolumn{2}{|c|}{1997} & \multirow[b]{2}{*}{$P$} & \multicolumn{2}{|c|}{1998} & \multirow[b]{2}{*}{$P$} \\
\hline & Observed & Expected & & Observed & Expected & \\
\hline Mature forest & 80.76 & $91.94 \pm 0.03$ & 0.0003 & 41.42 & $48.13 \pm 0.02$ & 0.0017 \\
\hline Insect-foliage & 86.02 & $92.29 \pm 0.02$ & 0.0050 & 52.96 & $65.15 \pm 0.02$ & $<0.0001$ \\
\hline Canopy nesters & 67.03 & $71.92 \pm 0.02$ & 0.0078 & 36.63 & $40.90 \pm 0.02$ & 0.0068 \\
\hline Species of concern & 136.11 & $147.68 \pm 0.12$ & 0.0049 & 73.32 & $85.04 \pm 0.03$ & 0.0001 \\
\hline
\end{tabular}

TABLE 3. Logistic regression coefficients and upper and lower $95 \%$ confidence intervals (C. I.) predicting occurrence across a habitat gradient for members of the mature forest (MF), insect-foliage (IF), canopy nesting (CN) and conservation concern (CC) species groups detected in 1997. The confidence intervals of the species in bold face do not overlap with the confidence interval of the Cerulean Warbler.

\begin{tabular}{|c|c|c|c|c|}
\hline Species & $\begin{array}{l}\text { Functional } \\
\text { group }\end{array}$ & $\begin{array}{l}\text { Regression } \\
\text { coefficient }\end{array}$ & $\begin{array}{c}\text { Lower } \\
95 \% \text { C. I. }\end{array}$ & $\begin{array}{c}\text { Upper } \\
95 \% \text { C. I. }\end{array}$ \\
\hline Cerulean Warbler (Dendroica cerulea) & all & 0.519 & 0.121 & 0.917 \\
\hline American Redstart (Setophaga ruticilla) & all & 0.144 & -0.299 & 0.587 \\
\hline Ovenbird (Seiurus aurocapilla) & $\mathrm{MF}, \mathrm{CC}$ & 0.475 & 0.024 & 0.926 \\
\hline Black-and-white Warbler (Mniotilta varia) & MF & -0.290 & -0.645 & 0.065 \\
\hline Scarlet Tanager (Piranga olivacea) & all & 0.106 & -0.239 & 0.451 \\
\hline Least Flycatcher (Empidonax minimus) & $\mathrm{MF}, \mathrm{CN}, \mathrm{CC}$ & 0.116 & -0.290 & 0.522 \\
\hline Yellow-throated Vireo (Vireo flavifrons) & $\mathrm{MF}, \mathrm{IF}, \mathrm{CN}$ & 0.066 & -0.381 & 0.513 \\
\hline Wood Thrush (Hylocichla mustelina) & $\mathrm{MF}, \mathrm{CC}$ & -0.287 & -0.791 & 0.217 \\
\hline Black-throated Green Warbler (Dendroica virens) & $\mathrm{MF}, \mathrm{CN}, \mathrm{CC}$ & 0.134 & -0.272 & 0.540 \\
\hline Northern Waterthrush (Seiurus noveboracensis) & MF & -0.195 & -0.777 & 0.387 \\
\hline Warbling Vireo (Vireo gilvus) & IF & -0.995 & -1.936 & -0.054 \\
\hline Ruffed Grouse (Bonasa umbellus) & MF & -0.140 & -0.620 & 0.340 \\
\hline Veery (Catharus fuscescens) & $\mathrm{MF}, \mathrm{CC}$ & -0.622 & -1.786 & 0.542 \\
\hline Yellow-rumped Warbler (Dendroica coronata) & $\mathrm{MF}, \mathrm{IF}, \mathrm{CN}$ & 0.009 & -0.483 & 0.501 \\
\hline Common Yellowthroat (Geothlypis trichas) & IF, CC & -0.192 & -0.555 & 0.171 \\
\hline Golden-winged Warbler (Vermivora chrysoptera) & IF, CC & -0.534 & -0.955 & -0.113 \\
\hline Indigo Bunting (Passerina cyanea) & IF, CC & -0.535 & -0.974 & -0.096 \\
\hline Chestnut-sided Warbler (Dendroica pensylvanica) & IF, CC & -0.705 & -1.438 & 0.028 \\
\hline Yellow Warbler (Dendroica petechia) & IF & -0.232 & -0.585 & 0.121 \\
\hline Black-capped Chickadee (Poecile atricapillus) & IF & 0.058 & -0.279 & 0.395 \\
\hline Rose-breasted Grosbeak (Pheucticus ludovicianus) & IF, CC & -0.725 & -1.270 & -0.180 \\
\hline Baltimore Oriole (Icterus galbula) & $\mathrm{IF}, \mathrm{CN}, \mathrm{CC}$ & 0.281 & -0.217 & 0.779 \\
\hline Blue-grey Gnatcatcher (Polioptila caerulea) & $\mathrm{IF}, \mathrm{CN}$ & -0.279 & -0.781 & 0.223 \\
\hline Cedar Waxwing (Bombycilla cedrorum) & $\mathrm{CN}$ & -0.066 & -0.440 & 0.308 \\
\hline Blue Jay (Cyanocitta cristata) & $\mathrm{CN}$ & -0.873 & -1.528 & -0.218 \\
\hline Eastern Wood-Pewee (Contopus virens) & $\mathrm{CN}, \mathrm{CC}$ & -0.202 & -0.670 & 0.266 \\
\hline American Crow (Corvus brachyrhynchos) & $\mathrm{CN}$ & -0.304 & -0.835 & 0.227 \\
\hline
\end{tabular}

foliage and conservation concern groups exhibited less concordance with the Cerulean Warbler distribution relative to the habitat gradient $-43 \%$ (6 of 14) and $29 \%$ (4 of 14), respectively.

\section{Discussion}

Effective biodiversity indicators tend to be habitat specialists with wide geographic ranges; they also tend to have well-known natural histories (Caro and O'Doherty 1999). Despite fitting this profile (Hamel 2000; Oliarnyk 1996; Jones 2000; Barg 2002), our results indicate that the Cerulean Warbler would not be par- ticularly effective as an avian biodiversity indicator in eastern Ontario, as its distribution across the studied landscape did not coincide with areas of high avian species richness.

Our co-occurrence and logistic regression results do suggest that the Cerulean Warbler is suited to a role as an umbrella species. Perhaps not surprisingly, the distribution of the Cerulean Warbler was well matched to the distributions of other canopy nesters in mature deciduous forest (e.g., Scarlet Tanager, Piranga olivacea). Given the hierarchical nature of habitat selection, broad habitat requirements are likely more impor- 
tant in determining species distributions than are species' food and nesting requirements (Hutto 1985; Block and Brennan 1993); indeed, we found that the species grouped by diet were more variable in their distributions along our succession gradient than were the species grouped by habitat type or nest location. Small body size - and, as a consequence, small home range size (Barg et al. in press) - could limit the Cerulean Warbler's umbrella suitability, as effective umbrella species tend to have large home ranges (Caro and O'Doherty 1999); however, the Cerulean Warbler's apparent tendency to live in conspecific aggregations (Hamel 2000) potentially offsets any limitation imposed by small body size and individual home range size. We do not mean to suggest that the Cerulean Warbler would be a better umbrella than other, more widespread, species such as the Scarlet Tanager. Rather, our conclusions suggest that, if habitat management is directed at Cerulean Warblers, other species will likely benefit.

Our co-occurrence and logistic regression results highlight a potential management conflict between mature forest and shrubland species. Although our $C$ scores indicate significant patterns of co-occurrence within the conservation concern group, there was no overlap between the logistic regression confidence intervals of the Cerulean Warbler and shrubland species that are considered to be at risk, such as the Goldenwinged Warbler (Vermivora chrysoptera). Given their disparate habitat requirements (i.e., forest edge vs. forest interior), management for Golden-winged Warblers will necessarily conflict with management aimed at maximizing Cerulean Warbler population health.

One additional conservation role the Cerulean Warbler may fill, and may be already filling, is that of a flagship species: a species that attracts attention support by virtue of its 'charismatic' nature (Simberloff 1998). The Cerulean Warbler is a Neotropical migrant songbird, a group of birds that has been in the conservation spotlight over the last 30 years (e.g., Robbins et al. 1989b). The Cerulean Warbler is a beautiful bird with an elusive nature that has a high profile due to extensive public education and activism (Rosenberg et al. 2002) and is highly valued by birders and ornithologists alike. More recently, the Cerulean Warbler has achieved notoriety as the focus of a legal battle surrounding its candidacy for listing on the U.S. Endangered Species Act (Ruley 2000). This attention has led to the development of the CWTG and has spurred a great deal of basic research and forest management interest (Hamel et al. 2004). The apparent dependence of this species on large tracts of forest creates a possibility for the Cerulean Warbler to serve as a valuable symbol of the overall health of deciduous forests in eastern North America.

\section{Acknowledgments}

We thank J. Pither and R. Montgomerie for statistical advice. J. Barg, A. Erskine and an anonymous reviewer provided helpful comments on earlier drafts. F. Phelan, M. Phelan, F. Connor and the staff at the Queen's University Biological Station provided logistical support. Funding was provided by B. and K. Jones, Wildlife Habitat Canada, the Eastern Ontario Model Forest Program and an NSERC operating grant to RJR. We also had the support of the World Wildlife Fund of Canada in the form of a MacNaughton Conservation Scholarship to JJ and grants from the Endangered Species Recovery Fund to RJR. This project is part of Natural Legacy 2000, a nationwide initiative in Canada to conserve wildlife and habitats in private and public. We gratefully acknowledge the support of the Government of Canada's Millennium Partnership Fund. JJ was also supported by an NSERC scholarship, Queen's Graduate Awards and the Queen's Bracken Fellowship.

\section{Documents Cited [marked $*$ in text]}

COSEWIC. 2003. COSEWIC Assessment and update status report on the Cerulean Warbler Dendroica cerulea in Canada. Report prepared by J. J. Barg, J. Jones, and R. J. Robertson. Committee on the Status of Endangered Wildlife in Canada. Ottawa, ON.

Gotelli, N. J., and G. L. Entsminger. 2000. EcoSim: null models software for ecology. Version 5.0. Acquired Intelligence Inc. \& Kesey-Bear.

Hood, G. 2002. PopTools, Version 2.3. http://www.cse. csiro.au/CDG/poptools/.

Mathsoft, Inc. 1997. S-Plus 4.0. Data Analysis Products Division, Mathsoft, Inc. Seattle, Washington.

Rosenberg, K. V., S. E. Barker, and R. W. Rohrbaugh. 2002. An atlas of Cerulean Warbler populations - Final report to United States Fish and Wildlife Service: 19972000 breeding seasons. Cornell Lab of Ornithology, Ithaca, New York.

Ruley, D. A. 2000. Petition under the Endangered Species Act to List the Cerulean Warbler, Dendroica cerulea, as a Threatened Species. Southern Environmental Law Center, Asheville, North Carolina.

SAS Institute Inc. 2000. JMP IN 4.0.2. SAS Institute Inc., Cary, North Carolina.

Sauer, J. R., J. E. Hines, and F. Fallon. 2001. The North American Breeding Bird Survey, Results and Analysis 1966-2000. Version 2001.2, USGS Patuxent Wildlife Research Center, Laurel, Maryland.

\section{Literature Cited}

Barg, J. J. 2002. Small-scale biological phenomena in a male Neotropical migrant songbird: space use, habitat use, and behaviour within territories of male Cerulean Warblers. M.Sc. thesis, Queen's University, Kingston, Ontario.

Barg, J. J., J. Jones, and R. J. Robertson. 2005. Describing breeding territories of migratory passerines: suggestions for sampling, choice of estimator, and delineation of core areas. Journal of Animal Ecology 74: 139-149.

Berger, J. 1997. Population constraints associated with the use of black rhinos as an umbrella species for desert herbivores. Conservation Biology 11: 69-78.

Block, W. M., and L. A. Brennan. 1993. The habitat concept in ornithology: theory and applications. Current Ornithology 11: 35-91. 
Canterbury, G. E., T. E. Martin, D. R. Petit, L. J. Petit, and D. F. Bradford. 2000. Bird communities and habitat as ecological indicators of forest condition in regional monitoring. Conservation Biology 14: 544-558.

Caro, T. M., and G. O'Doherty. 1999. On the use of surrogate species in conservation biology. Conservation Biology 13: 805-814.

Chase, M. K., W. B. Kristan III, A. J. Lynam, M. V. Price, and J. T. Rotenberry. 2000. Single species as indicators of species richness and composition in California coastal sage scrub birds and small mammals. Conservation Biology 14: 474-487.

Ehrlich, P. R., D. S. Dobkin, and D. Wheye. 1988. The birder's handbook. Simon \& Schuster, New York.

Feeley, K. 2003. Analysis of avian communities in Lake Guri, Venezuela, using multiple assembly rule models. Oecologia 137: 104-113.

Freemark, K., and B. Collins. 1992. Landscape ecology of birds breeding in temperate forest fragments. Pages 443454 in Ecology and conservation on Neotropical migrant landbirds. Edited by J. M. Hagan III and D. W. Johnston. Smithsonian Institution Press, Washington, DC.

Gotelli, N. J., and D. J. McCabe. 2002. Species co-occurrence: a meta-analysis of J. M. Diamond's assembly rules model. Ecology 83: 2091-2096.

Hamel, P. B. 2000. Cerulean Warbler (Dendroica cerulea). Number 511 in The birds of North America. Edited by A. Poole and F. Gill. Academy of Natural Sciences, Philadelphia, and American Ornithologists' Union, Washington, DC.

Hamel, P. B, D. K. Dawson, and P. D. Keyser. 2004. How we can learn more about the Cerulean Warbler (Dendroica cerulea). Auk 121: 7-14.

Hutto, R. L. 1985. Habitat selection by nonbreeding, migratory land birds. Pages 455-476 in Habitat selection in birds. Edited by M. L. Cody. Academic Press, New York.

Jones, J. 2000. Assessing conservation utility: a case study of the cerulean warbler in eastern Ontario. Ph.D. dissertation, Queen's University, Kingston, Ontario.

Jones, J., J. J. Barg, T. S. Sillett, M. L Veit, and R. J. Robertson. 2004. Survival and population growth rates of Cerulean Warblers breeding in Ontario, Canada. Auk 121: $15-22$.

Jones, J., R. D. DeBruyn, J. J. Barg, and R. J. Robertson. 2001. Assessing the effects of natural disturbance on a Neotropical migrant songbird. Ecology 82: 2628-2635.

Jones, J., W. J. McLeish, and R. J. Robertson. 2000. Density influences census technique accuracy for Cerulean
Warblers in eastern Ontario. Journal of Field Ornithology $71: 46-56$

Jones, J., and R. J. Robertson. 2001. Territory and nest-site selection of Cerulean Warblers in eastern Ontario. Auk 118: 727-735.

Landres, P. B., J. Verner, and J. W. Thomas. 1988. Ecological uses of vertebrate indicator species: a critique. Conservation Biology 2: 316-327.

Launer, A. E., and D. D. Murphy. 1994. Umbrella species and the conservation of habitat fragments: a case of a threatened butterfly and a vanishing grassland ecosystem. Biological Conservation 69: 145-153.

Link, W. A., and J. R. Sauer. 2002. A hierarchical analysis of population change with application to Cerulean Warblers. Ecology 83: 2832-2840.

Oliarnyk, C. J. 1996. Habitat selection and reproductive success in a population of Cerulean Warblers in southeastern Ontario. M.Sc. thesis, Queen's University, Kingston, Ontario.

Oliarnyk, C. J., and R. J. Robertson. 1996. Breeding behavior and reproductive success of Cerulean Warblers in southeastern Ontario. Wilson Bulletin 108: 673-684.

Peres-Neto, P. R., D. A. Jackson, and K. M. Somers. 2003. Giving meaningful interpretation to ordination axes: assessing loading significance in principal component analysis. Ecology 84: 2347-2363.

Reynolds, R. T., J. M. Scott, and R. A. Nussbaum. 1980. A variable circular-plot method for estimating bird numbers. Condor 82: 309-313.

Robbins, C. S., D. S. Dawson, and B. A. Dowell. 1989a. Habitat area requirements of breeding forest birds of the middle Atlantic states. Wildlife Monographs 103: 1-34.

Robbins, C. S., J. R. Sauer, R. Greenberg, and S. Droege. 1989b. Population declines in North American birds that migrate to the Neotropics. Proceedings of the National Academy of Science, USA 86: 7658-7662.

Robbins, C. S., J. W. Fitzpatrick, and P. B. Hamel. 1992. A warbler in trouble: Dendroica cerulea. Pages 549-562 in Ecology and conservation of Neotropical migrant landbirds. Edited by J. M. Hagan III and D. W. Johnston. Smithsonian Institution Press, Washington, D.C.

Simberloff, D. 1998. Flagships, umbrellas, and keystones: is single-species management passé in the landscape era? Biological Conservation 83: 247-257.

Stone, L., and A. Roberts. 1990. The checkerboard score and species distributions. Oecologia 85: 74-79.

Received 22 October 2002

Accepted 21 July 2004 